\title{
各種ゴムの劣化機構（ II）
}

\section{太 智 重 光}

\section{Degradation Mechanism of Rubbers :Part II}

Shigemitsu OTOMO (Retired from Ouchishinko Chemical Industrial Co.,Ltd.) otomo1234@tba.t-com.ne.jp

In order to prevent ageing of rubber, it is important to understand the degradation mechanism of rubber. Autoxidation mechanism and the heat oxidative degradation mechanisms of various rubbers were reported in the previous paper.

In this article, the various degradation mechanisms of other rubbers, ozone cracking mechanism of diene rubber and the mechanism of autoxidation reaction accelerated with transition metal or UV light are explained from the viewpoint of chemical reaction.

(Received on March 25, 2019)

Key Words : Rubber, Degradation Mechanism, Ozone Cracking, Acceleration of Degradation, Transition Metal, UV Light, Heat Aging, Hydrolysis

\section{1. は じめ に}

ゴム製品の多くは使用中に，酸化劣化，オゾン劣化，疲 労劣化などの各種劣化を受け，出荷時にデザインされてい た各種物性や風合い・色調などが，時間とともに失われて いく．そのため何れのゴム製品でも劣化を防ぐための各種 方策が取られているが，より効果的に劣化を防止するため には，各種ゴムの劣化機構を把握することが重要となる.

ゴム製品が受ける各種劣化のうち，酸化劣化と密接な関 係にある自動酸化反応の作用機構，ならびに主なゴムの酸 化劣化の作用機構については, 本誌ですでに紹介した ${ }^{11}$.

本稿ではその他のゴムの各種劣化機構，太陽光と遷移金 属による酸化劣化の促進作用機構ならびにオゾン劣化の作 用機構について, 化学反応の観点から紹介する.

\section{2. 各種ゴムの劣化機構}

\section{1 各種ゴムの劣化機構}

各種ゴムの劣化機構の説明に際し，一部のゴムについて は酸化劣化に伴うモジュラスと硬さの変化の平均值と標準 偏差值が記載された表を本文中に示している。 これらの表
に記載されたデー夕は, NOC技術ノートに紹介された老化 防止剂が添加されていない加硫物の耐熱酸化性の評価結果 である。モジュラスと硬さは加硫密度と比例関係にあるこ とから, 主鎖切断反応やゲル化反応からなるゴムの劣化挙 動の特徴を表すものと考えられ, 前報 ${ }^{1)}$ と同様に劣化機構 考察の一助とした.

\subsection{1 高飽和ニトリルゴム（HNBR）の劣化機構}

$\mathrm{HNBR}$ は, NBR の $\mathrm{C}=\mathrm{C}$ を選択的に水素添加して製造さ れる。 その際，1,2-ブタジエンユニットが優先的に水素添 加されるため, HNBRは図1に示すように, 一部水素添加 されなかった 1,4 -構造を加硫点として有するミクロ化学構 造を有し2)，またニトリル基による耐油性も維持されてい る.さらにHNBRの耐酸化性と耐オゾン劣化性は, $\mathrm{C}=\mathrm{C}$

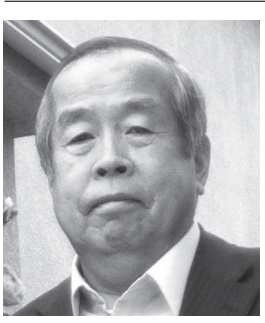

太智 重光; 元大内新興化学工業侏顧問. 1973 年, 京都工芸繊維大学大学院修士課程修了. 同 年, 大内新興化学工業(侏)入社, 中央研究所次長, 取締役生産管理部長，中国合弁会社董事副総経 理（兼任）などを経て，2015年退社. 専門は, ゴム薬品の開発商品化. 


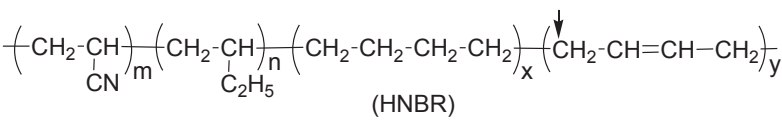

図 1 HNBRのミクロ化学構造と酸化劣化の開始点 ${ }^{2)}$

表1 HNBR拄よびNBR加硫物の酸化劣化に伴うモジュラスと硬さの 変化状況

\begin{tabular}{|c|c|c|c|c|}
\hline ゴム & \multicolumn{4}{|c|}{$\mathrm{HNBR}$} \\
\hline 劣化条件 & \multicolumn{1}{|c|}{$150{ }^{\circ} \mathrm{C} * 24 \mathrm{~h}$} & \multicolumn{2}{|c|}{$150{ }^{\circ} \mathrm{C} * 48 \mathrm{~h}$} \\
\hline 物性 & $S_{100}$ & $H \mathrm{~s}$ & $S_{100}$ & $H \mathrm{~s}$ \\
\hline 変化の平均值 & +52.2 & +4.1 & +81.9 & +7.0 \\
\hline 偏差值 & 2.6 & 0.3 & 2.8 & 0.0 \\
\hline (デー夕数 $)$ & $(9)$ & $(9)$ & $(9)$ & $(9)$ \\
\hline \hline ゴム & \multicolumn{5}{|c|}{$\mathrm{NBR}$} \\
\hline 劣化条件 & $120{ }^{\circ} \mathrm{C} * 48 \mathrm{~h}$ & $120{ }^{\circ} \mathrm{C} * 96 \mathrm{~h}$ \\
\hline 物性 & $S_{100}$ & $H \mathrm{~s}$ & $S_{100}$ & $H \mathrm{~s}$ \\
\hline 変化の平均值 & $+63.7 \%$ & +8.7 & $+128.0 \%$ & +10.6 \\
\hline 偏差值 & 12.8 & 2.5 & 60.1 & 2.7 \\
\hline (データ数 $)$ & $(14)$ & $(14)$ & $(5)$ & $(5)$ \\
\hline
\end{tabular}

含有量が少ない分, NBRより高い.

HNBR 加硫物は, 表 1 に示したように酸化劣化の進行に 伴い, ゲル化反応が進行してモジュラスと硬さが増加する が, その程度は劣化温度が高いにもかかわらずNBR加硫物 より低い. HNBRは, 図 2 に示すように, 基本的にNBR加 硫物と同様の劣化機構で進行し, 各種ラジカルの $\mathrm{C}=\mathrm{C}$ 一 の付加反応（図2式（iii）参照）や再結合反応（図2式（iv） 参照)が加硫物の物性変化に大きく影響したと考えられる.

\subsection{2 ブチルゴム（IIR）の劣化機構}

IIR は図 3 に示すように, イソブチレンユニットと少量の イソプレンユニットからなるミクロ化学構造を有する3). IIRの代表的加硫方法として硫黄加硫, キノイド加硫, 樹 脂加硫があるが, IIR加硫物の劣化挙動は加硫方法により 大きく異なる．表 2 には各種 IIR加硫物の $150{ }^{\circ} \mathrm{C}$ での酸化劣

(i) $-\mathrm{HNBR}-\mathrm{CH}_{2}-\mathrm{CH}=\mathrm{CH}-\mathrm{CH}_{2}-\stackrel{\Delta}{\longrightarrow}-\underset{6}{\mathrm{CH}}-\mathrm{CH}=\mathrm{CH}-\mathrm{CH}_{2}-\stackrel{\mathrm{O}_{2}}{\longrightarrow}$ $(\mathrm{R} \bullet)$

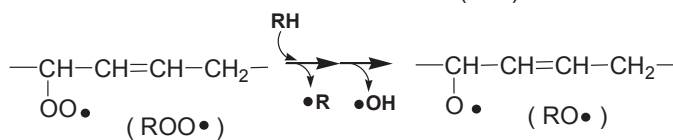

(ii) $-\mathrm{CH}_{2}-\mathrm{CH}-\mathrm{CH}=\mathrm{CH}-\mathrm{CH}_{2}-\longrightarrow-\mathrm{CH}_{2} \bullet+\mathrm{CH}-\mathrm{CH}=\mathrm{CH}-\mathrm{CH}_{2}-$ O.

O

(iii) $\mathrm{R} \bullet+-\mathrm{CH}_{2}-\mathrm{CH}=\mathrm{CH}-\mathrm{CH}_{2}-\longrightarrow-\mathrm{CH}_{2}-\mathrm{CH}-\mathrm{CH}-\mathrm{CH}_{2}-$ $(\mathrm{RO} \bullet, \mathrm{ROO} \bullet)$ $\mathrm{R}(-\mathrm{OR},-\mathrm{OOR})$

(iv) $\mathrm{R} \bullet / \mathrm{RO} \bullet / \mathrm{ROO} \bullet \longrightarrow \mathrm{R}-\mathrm{R} / \mathrm{ROR} / \mathrm{ROOR}$

図2 HNBRの劣化機構<smiles>CC(C=[18O])=CCC(C)(C)CC(C)(C)C</smiles>

図3 IIRのミクロ化学構造 ${ }^{3)}$
化に伴うモジュラスと硬さの変化を示す。硫黄加硫物とキ ノイド加硫物は酸化劣化に伴いモジュラスと硬さが減少 し，特に硫黄加硫物では短時間で著しく減少しているのが わかる。これらの結果は, IIRのキノイド加硫物では酸化 劣化に伴い主に主鎖開裂反応が進行するのに対し，硫黄加 硫物では主鎖開裂反応と硫黄加硫鎖の崩壊反応の両方が起 こっているという報告 ${ }^{4)}$ とよく一致する.

IIRのキノイド加硫物の劣化機構としては，主鎖開裂反 応で生成したポリマーラジカル（I）と（II）に酸素が反応 して, ポリマーオキシラジカル $(\mathrm{RO} \cdot)$ とポリマーペルオ キシラジカル $(\mathrm{ROO} ・)$ が生成する（図4式（i），(ii）参 照).そして最終的に, 図4の式 (iii) および式 (iv) に示 したように，水素引抜き反応で生成したポリマーラジカル の $\beta$-開裂反応による主鎖切断が進行すると考えられている ${ }^{5)}$. 一方，硫黄加硫物では図 4 に示した主鎖開裂反応のほかに, イソプレンユニットで形成された硫黄加硫鎖が図 5 に従っ て開裂するため ${ }^{1)}$ ，加硫物の物性が大きく低下したと考え

表2 各種IIR加硫物の酸化劣化に伴うモジュラスと硬さの変化状況

\begin{tabular}{|c|c|c|c|c|}
\hline ゴム & \multicolumn{4}{|c|}{ IIR 硫黄加硫物 } \\
\hline 劣化条件 & \multicolumn{2}{|c|}{$150{ }^{\circ} \mathrm{C} * 24 \mathrm{~h}$} & \multicolumn{2}{c|}{$150{ }^{\circ} \mathrm{C} * 48 \mathrm{~h}$} \\
\hline 物性 & $S_{100}$ & $H \mathrm{~s}$ & \multicolumn{1}{|c|}{$S_{100}$} & $H \mathrm{~s}$ \\
\hline 変化の平均値 & -41.0 & -4.5 & -50.0 & -6.0 \\
\hline 偏差值 & 29.7 & 3.5 & 32.5 & 4.2 \\
\hline (データ数 $)$ & $(2)$ & $(2)$ & $(2)$ & $(2)$ \\
\hline \hline ゴム & \multicolumn{5}{|c|}{$\mathrm{IIR}$ キノイド加硫物 } \\
\hline 劣化条件 & $150{ }^{\circ} \mathrm{C} * 8$ 日 & \multicolumn{1}{c|}{$150{ }^{\circ} \mathrm{C} * 16$ 日 } \\
\hline 物性 & $S_{100}$ & $H \mathrm{~s}$ & $S_{100}$ & $H \mathrm{~s}$ \\
\hline 変化の平均值 & -3.5 & 0.0 & -18.0 & -1.5 \\
\hline 偏差值 & 12.0 & .4 & 18.4 & 0.7 \\
\hline (データ数 $)$ & $(2)$ & $(2)$ & $(2)$ & $(2)$ \\
\hline \hline ゴム & \multicolumn{5}{|c|}{$\mathrm{IIR}$ 樹脂加硫物 } \\
\hline 劣化条件 & $150{ }^{\circ} \mathrm{C} * 8$ 日 & $150{ }^{\circ} \mathrm{C} * 16$ 日 \\
\hline 物性 & $S_{100}$ & $H \mathrm{~s}$ & $S_{100}$ & $H \mathrm{~s}$ \\
\hline 変化の平均值 & +53.5 & +5.0 & +37.5 & +4.5 \\
\hline 偏差值 & 21.9 & 0.0 & 38.9 & 0.7 \\
\hline (データ数 $)$ & $(2)$ & $(2)$ & $(2)$ & $(2)$ \\
\hline
\end{tabular}

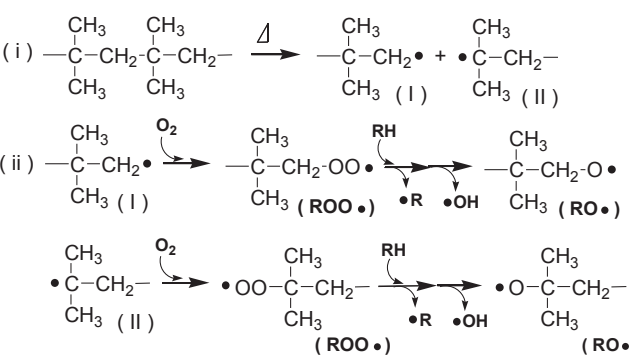

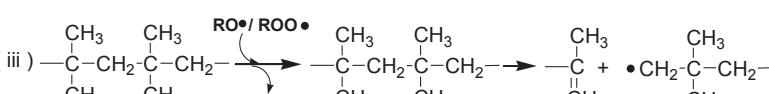
$\mathrm{CH}_{3} \quad \mathrm{CH}_{3}$ ROH /ROOH $\mathrm{CH}_{2} \quad \mathrm{CH}_{3} \quad \mathrm{CH}_{2} \quad \mathrm{CH}_{3}$

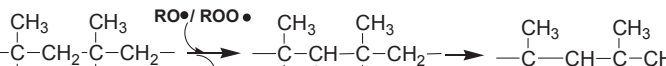
$\mathrm{CH}_{3} \quad \mathrm{CH}_{3} \quad \mathrm{ROH} / \mathrm{ROOH} \mathrm{CH}_{3}^{\circ} \mathrm{CH}_{3} \quad \mathrm{CH}_{3} \mathrm{CH}_{3} \cdot \mathrm{C}_{2}$

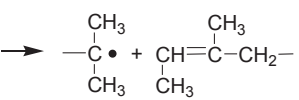

図4 IIR キノイド加硫物の劣化機構 ${ }^{5}$ 
られる。

一方, 樹脂加硫物ではキノイド加硫物および硫黄加硫物 とは異なり,酸化劣化によりゲル化反応が進行して, モジュ ラスと硬さが増加する (表2). 樹脂加硫物が前出の両加硫 物と異なる特徵として，加硫鎖にフェノール骨格を有する ことがあげられる，そのため樹脂加硫物では，酸化劣化の 過程でフェノール系老化防止剂と同様の反応 ${ }^{6)}$ が進行する と考えられる。即ち，加硫鎖を構成するフェノール性水酸 基が, 図6に示すようにポリマーオキシラジカル（RO・） に水素を供与してフェノオキシラジカルが生成され，その 後にポリマーペルオキシラジカル $(\mathrm{ROO} ・)$ との再結合反 応（ゲル化反応）が進行すると考えられる．そしてこのゲ ル化反応の加硫物の物性への影響度が，主鎖開裂反応より 大きいため, 酸化劣化により加硫物のモジュラスと硬さが 増加したと考えると無理がなく理解しやすい.

\subsection{3 ポリウレタンエラストマー（TPU）の劣化機構}

TPUはポリマーグリコール，短鎖グリコール（鎖延長 剂)，ジイソシアネートの三元共重合体であるが，TPUの 特性は用いたポリマーグリコールの種類で大きく異なる.

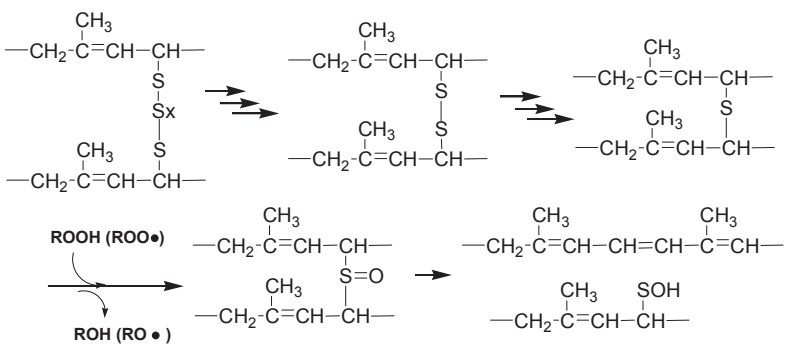

図 5 IIR 硫黄加硫物の劣化機構 ${ }^{1)}$
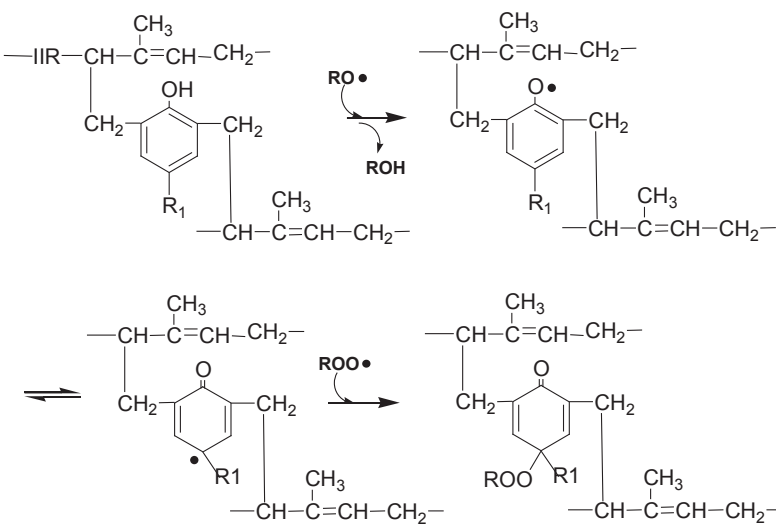

$\mathrm{CH}_{3}$

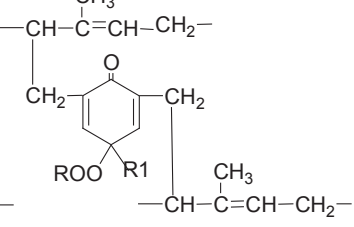

図6 IIR 樹脂加硫物の劣化機構
図7には代表的TPUの化学構造を, 表3には各種ポリマー グリコールをソフトセグメントに用いたTPUの特性を示

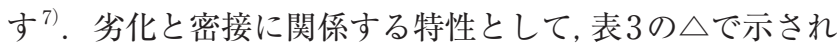
たポリエステル・アジペート系の耐加水分解性の低さとポ リエーテル系の耐熱性の低さが挙げられる。

ポリエステル・アジペート系の耐加水分解性の低さは, ソフトセグメントに用いたポリマーグリコールに含まれる エステル結合に起因する。エステル結合は, ウレタン結合 やアロハナート結合などTPUを構成する何れの結合より 加水分解されやすいため ${ }^{8)}$, 図 8 式（i）に示した劣化機構 に従って, エステル結合が加水分解されてアルコールとカル ボン酸となる主鎖開裂反応が進行すると考えられている ${ }^{8)}$.

一方, ポリエーテル系TPUの耐熱性の低さは, ソフトセ グメントに用いたポリマーグリコールのエーテル結合に起 因し, 図8式（ii）に示した劣化機構に従って, エーテル結 合に隣接したメチレン基で酸化開裂反応が生じていると考 えられている ${ }^{8)}$.

\section{(1)ポリエステル系}

$\left.-\mathrm{O}-\mathrm{R}_{4}-\mathrm{O}-\mathrm{O}-\mathrm{O}-\mathrm{NH}-\mathrm{R}_{1}-\mathrm{NH}-\mathrm{C}-\mathrm{C}-\mathrm{O}\left(\mathrm{R}_{2}-\mathrm{O}-\mathrm{O}-\mathrm{O}-\mathrm{R}_{3}-\mathrm{O}-\mathrm{O}-\mathrm{O}\right)_{\mathrm{x}}^{\mathrm{O}} \stackrel{\mathrm{C}}{\mathrm{C}}-\mathrm{NH}-\mathrm{R}_{1}-\mathrm{NH}-\stackrel{\mathrm{O}}{\mathrm{C}}\right]_{\mathrm{n}}$

(2)ポリエーテル系

$\left[-\mathrm{O}-\mathrm{R}_{4}-\mathrm{O}-\mathrm{O}-\mathrm{C}-\mathrm{NH}-\mathrm{R}_{1}-\mathrm{NH}-\mathrm{O}-\mathrm{C}-\mathrm{O}\left(\mathrm{R}_{2}-\mathrm{O}\right)_{\mathrm{x}}^{\mathrm{O}} \mathrm{O}-\mathrm{NH}-\mathrm{R}_{1}-\mathrm{NH}-\mathrm{O}-\mathrm{C}\right]_{n}$

(3)ポリカーボネート系

$\left[-\mathrm{O}-\mathrm{R}_{4}-\mathrm{O}-\mathrm{O}-\mathrm{C}-\mathrm{NH}-\mathrm{R}_{1}-\mathrm{NH}-\mathrm{O}-\mathrm{O}-\mathrm{O}\left(\mathrm{R}_{2}-\mathrm{O}-\mathrm{O}-\mathrm{O}-\mathrm{O}\right)_{\mathrm{x}}^{\mathrm{O}} \mathrm{C}-\mathrm{NH}-\mathrm{R}_{1}-\mathrm{NH}-\stackrel{\mathrm{C}}{\mathrm{C}}\right]_{\mathrm{n}}$ 図7 代表的TPUのミクロ化学構造 ${ }^{7)}$

（i）エステル系 TPU の加水分解機構

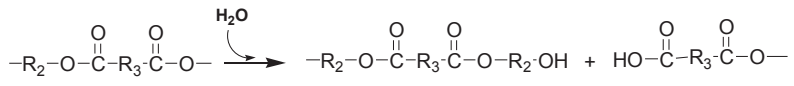

（ii）エーテル系 TPU の熱劣化機構

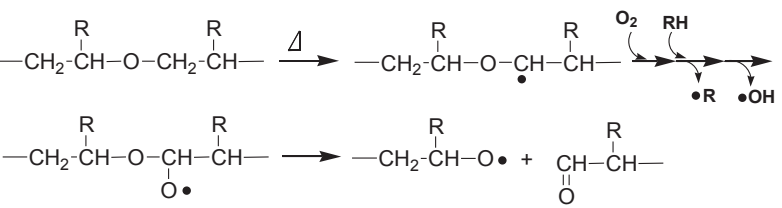

図 8 TPUの劣化機構 ${ }^{8)}$

表3 各種長鎖ポリオールをソフトセグメントに用いたTPUの特性 ${ }^{7)}$

\begin{tabular}{|c|c|c|c|c|}
\hline \multirow[b]{2}{*}{ 特性 } & \multicolumn{2}{|c|}{ ポリエステルポリオール } & ポリエーテルポリオール & \multirow{2}{*}{$\begin{array}{c}\text { ポリカーボ } \\
\text { ナート } \\
\text { ポリオール }\end{array}$} \\
\hline & アジペート系 & $\begin{array}{l}\text { ポリカプロ } \\
\text { ラクトン系 }\end{array}$ & $\begin{array}{l}\text { ポリテトラメチレン } \\
\text { エーテルグリコール }\end{array}$ & \\
\hline 機械強度 & (a) & (O) & $\bigcirc$ & (a) \\
\hline 低温特性 & O & O & (a) & O \\
\hline 耐熱性 & $\bigcirc$ & (a) & $\triangle$ & (2) \\
\hline 耐加水分解性 & $\triangle$ & O & (a) & (a) \\
\hline 耐油性 & (a) & (a) & (a) & (a) \\
\hline 耐菌性 & $\triangle$ & $\triangle$ & 0 & $\bigcirc$ \\
\hline
\end{tabular}




\subsection{4 シリコーンゴムの劣化機構}

シリコーンゴムを加熱処理したときの重量減少の状況は 劣化環境で異なり, 図9に示したように窒素中で加熱処理 されると, 空気中より大きな重量減少が観察される ${ }^{9)}$.

シリコーンゴムの劣化は，ゴム表面では側鎖メチル基の 酸化劣化によるゲル化反応（図10式（i）参照）が, 内部で は $350{ }^{\circ} \mathrm{C}$ 以上の高温環境下のためポリマー主鎖が開裂し, 揮発性の環状シロキサンが生成される（図10式 (ii) 参照) ${ }^{9}$. このためシリコーンゴムの窒素中の熱劣化では，ゴム表面 でのゲル化反応が進行しない分, 空気中より分解物の環状 シロキサンの揮発が進み，大きな重量減少が観察されると のことである ${ }^{9)}$.

\subsection{5 フッ素ゴム (FKM) の劣化機構}

$\mathrm{FKM}$ のミクロ化学構造は大半が C-F 結合で形成されて いるため，自動酸化による劣化は受けにくく，高い耐熱酸 化性と耐油性を示すが，アミン化合物による劣化現象が観 察されている。即ち，フッ化ビニリデン $(\mathrm{VF} 2)$ とへキサ フロロプロピレン（HFP）を共重合したFKMは，アルカ リ性の防錆剂や酸化防止剂を含んだSF 級あるいはSG 級の エンジンオイルにさらされると，ゴム表面が硬化し，いわ ゆる脆化現象が観察される ${ }^{10)}$ 。一例として SF 級オイルに $150{ }^{\circ} \mathrm{C} ， 48$ 時間浸漬した時の物性変化を表 4 に示す ${ }^{11)}$. こ の時の劣化機構としては, アミンなどの求核試薬の攻撃に

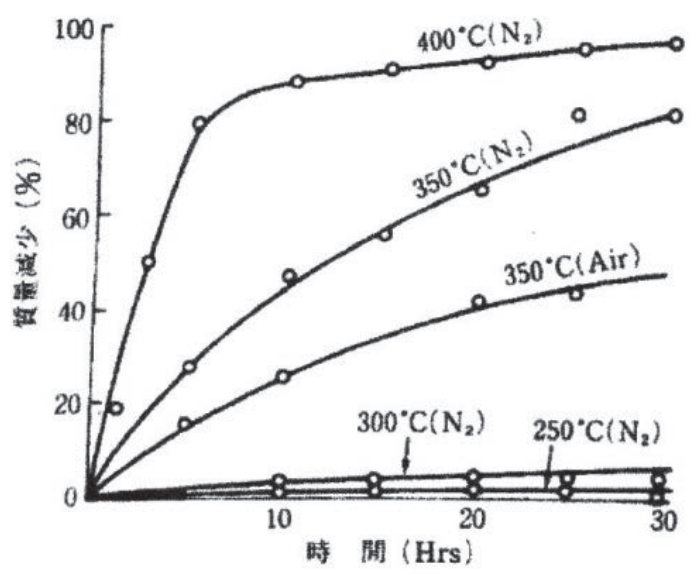

図9 ジメチルポリシロキサンの熱劣化挙動9)

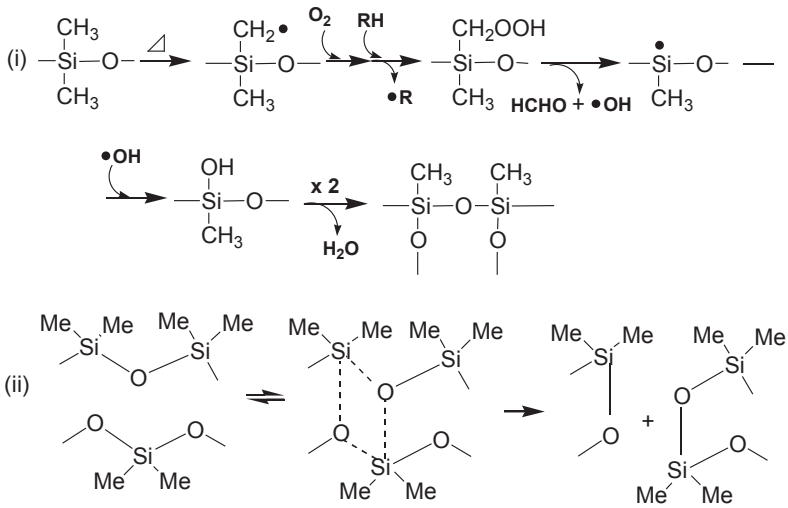

図 10 シリコーンゴムの劣化機構 ${ }^{9}$
表4 FKM加硫物の耐 SF 級オイル特性 ${ }^{11)}$

\begin{tabular}{|c|c|c|c|}
\hline フッ素ゴム & FKM-A & FKM-B & FKM-C \\
\hline フッ素含有量 & 66 & 68 & 70 \\
\hline \multicolumn{4}{|l|}{ 常態物性 } \\
\hline$T \mathrm{~b}(\mathrm{MPa})$ & 13.4 & 13.1 & 14.0 \\
\hline Eb (\%) & 280 & 250 & 175 \\
\hline 硬さ (Shore A) & 73 & 80 & 83 \\
\hline \multicolumn{4}{|c|}{ 耐 SF 級オイル $\left(150{ }^{\circ} \mathrm{C}, 48 \mathrm{~h}\right)$} \\
\hline$T \mathrm{~b}$ 変化率 $(\%)$ & -54 & -31 & -24 \\
\hline$E \mathrm{~Eb}$ 変化率（\%） & -57 & -41 & -41 \\
\hline 硬さ変化 $(\mathrm{Pt})$ & +4 & 0 & +2 \\
\hline 体積変化率 (\%) & +0.90 & +0.87 & +0.76 \\
\hline
\end{tabular}

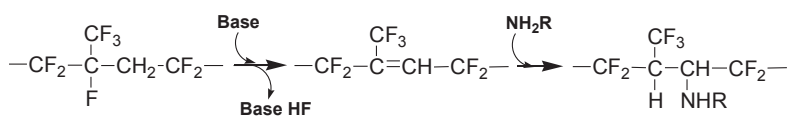

図11 フッソゴム (VF2-HFP) のアミンによる劣化機構 ${ }^{10)}$

よる脱 HF 反応とアミン化合物の付加反応 (ゲル化反応) が 考えられている (図 11参照) ${ }^{10)}$.

\section{2 酸化劣化を促進する要因とその作用機構}

ゴムに限らずポリマーの酸化劣化は，使用温度が高くな るとより進行し，物性が著しく低下することはよく経験す ることである。 これは使用温度の上昇に伴い, 自動酸化反 応で生成したヒドロペルオキシドの分解反応ならびに各種 ポリマーラジカルによるポリマー主鎖からの水素引抜き反 応が加速されるためである。

ポリマーの酸化劣化は劣化温度以外に, ポリマー中に含 まれている遷移金属や太陽光の照射によっても促進され る. 以下, これらの酸化促進状況とその作用機構について 述べる.

\section{2.1 遷移金属による酸化劣化の促進作用機構}

ゴム，樹脂を問わず多くのポリマーの酸化劣化は，自動 酸化反応に従って進行するが，ポリマー中に遷移金属が含 まれているとポリマーの酸化劣化は一段と進行する。表 5 は天然ゴム $(\mathrm{NR})$ 加硫物の $100{ }^{\circ} \mathrm{C} て ゙ の$ 耐熱酸化性に及ぼす ステアリン酸銅の添加効果を示す ${ }^{12)}$ 。表5から，ステアリ ン酸銅の添加により酸化劣化が加速されているのがわか る. 同様の効果はステアリン酸鉄についても確認されてい る ${ }^{13)}$.これらの銅塩および鉄塩による酸化劣化の促進作用 機構は, 図 12 に示した酸化還元反応によりヒドロペルオキ シドの分解反応が加速されるためと考えられている ${ }^{14)}$.

\section{2.2 太陽光による酸化劣化の促進作用機構}

多くのゴム製品にはカーボンブラックが配合されている

表5 NR加硫物の耐熱老化性への銅塩の影響 12

\begin{tabular}{|c|c|c|c|c|c|c|}
\hline \multirow{2}{*}{$\begin{array}{c}\text { ステアリン } \\
\text { 酸銅 } \\
(\mathrm{phr})\end{array}$} & \multirow{2}{*}{$\begin{array}{c}\text { 老化 } \\
\text { 時間 } \\
\text { (h) }\end{array}$} & \multicolumn{4}{|c|}{ 変化率（\%） } & 変化 \\
\hline & & $\begin{array}{c}T \mathrm{~b} \\
(\mathrm{MPa})\end{array}$ & $\begin{array}{l}E \mathrm{~b} \\
(\%)\end{array}$ & $\begin{array}{c}S_{100} \\
(\mathrm{MPa})\end{array}$ & $\begin{array}{c}S_{200} \\
(\mathrm{MPa})\end{array}$ & $H \mathrm{~s}$ \\
\hline \multirow{2}{*}{0} & 0 & 27.8 & 480 & 2.2 & 6.0 & 60 \\
\hline & 72 & -56 & -40 & +14 & +20 & -2 \\
\hline \multirow{2}{*}{0.5} & 0 & 27.4 & 500 & 2.3 & 6.4 & 61 \\
\hline & 72 & -74 & -48 & -4 & -8 & -5 \\
\hline
\end{tabular}




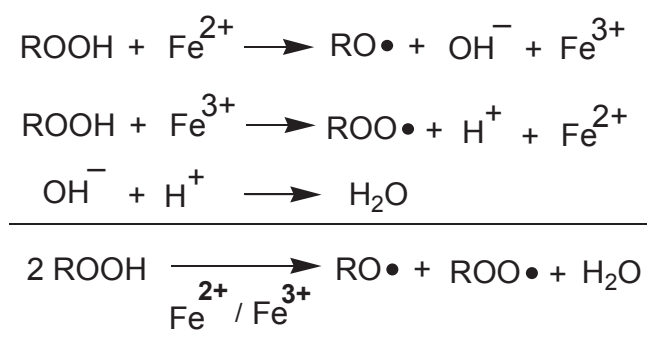

図 12 遷移金属による酸化劣化促進作用機構 ${ }^{14}$

ため通常は太陽光による酸化劣化は問題とならない。しか し，白色配合では表面層ではあるが，光が透過して酸化劣 化が進行し，物性変化が観察されることが少なくない．地 球上に到達する太陽光は $290 \mathrm{~nm}$ より大きい波長を有し, エ ネルギー的に高い近紫外部（290〜400 nm）の光が, 光酸 化劣化を促進する ${ }^{15,16)}$.

近紫外部の太陽光はNR加硫物の各種結合を解離するに 足りるエネルギーを有するが ${ }^{17)}$, 劣化への影響の程度は劣 化環境で大きく異なる. 即ち, 各種温度でNR過酸化物加 硫物に近紫外部の紫外線（ $\left.\lambda_{\text {max }}: 365 \sim 366 \mathrm{~nm}\right)$ を照射し た時，窒素中で紫外線を照射しても，応力緩和曲線に大き な変化は観察されないのに対し, 空気中で紫外線を照射す ると， $30 \sim 60{ }^{\circ} \mathrm{C}$ とう低温にもかかわらず，著しく応力 緩和が進行することが報告されている ${ }^{18)}$ 。このことから近 紫外部の紫外線自体がNR加硫物の主鎖開裂反応等に関与 しているのではなく，紫外線照射により自動酸化反応が促 進され，酸化劣化が加速されていると考えられる.

一方，このような近紫外部の紫外線による酸化劣化の促 進作用は，ゴム中に生成したカルボニル基と深く関係する ことが明らかにされている. 図13は事前に一重項酸素で酸 化処理され，分子中にヒドロペルオキシド基を含有（10 mol/ll) したイソプレンゴム（図14の式（ii）構造式 (I) ) をジクロロエタンに溶解した後, 紫外線 $(313 \mathrm{~nm})$ を照射 した時の主鎖開裂反応への二種類のケトンの添加効果を示 す ${ }^{19)}$. 図 13 より, ケトンの添加量に比例してイソプレンゴ ム（IR）の主鎖切断反応が加速されているのがわかる．図

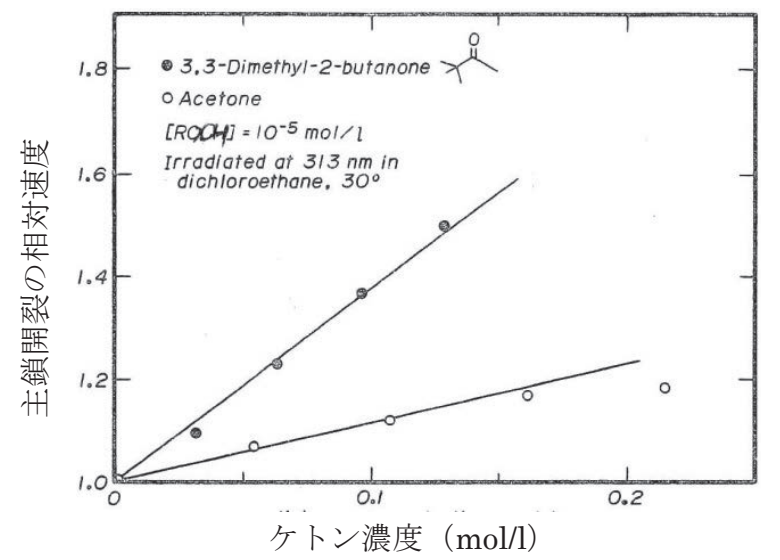

図 13 ヒドロペルオキシド化IRの主鎖開裂に対するケトンの促進効果 ${ }^{19)}$
14 には，紫外線によるIRの酸化劣化促進作用機構を示す. 加工段階でIR主鎖中に生成されたケト基が先ず紫外線で 励起される. その後, 励起されたケト基からヒドロペルオ キシド基に励起エネルギーが移動することで，ヒドロペル オキシドが開裂し，そして最終的に生成したポリマーオキ シラジカルが $\beta$ - 開裂反応を起こし，主鎖が開裂すると考え られている ${ }^{19)}$

\section{3 オゾンによるゴムの劣化機構}

オゾンは強い酸化力を有し, エチレンプロピレンゴム (EPR) 等の非ジエン系ゴムとも反応するが, ジエン系ゴム とオゾンとの反応性はEPRに比べると著しく高い. EPR オゾンとの反応性を 1 とした場合のジエン系ゴムの反応性 は, $\mathrm{CR}: 7.0 \times 10^{4}, \mathrm{SBR}: 1.0 \times 10^{6}, \mathrm{NR}: 7.3 \times 10^{6}$ と, $\mathrm{EPR}$ 対比で数万倍〜数百万倍にも達する ${ }^{20)}$. そのためジエン系 ゴムにEPRやEPDMをブレンドして耐オゾン性を向上さ せることも珍しくない．オゾンによるジエン系ゴムの劣化 機構を図15に示す.オゾンがジエン系ゴムを攻撃すること で，主鎖の二重結合へのオゾンの付加反応を経て，オゾニ ドが生成すると考えられている ${ }^{20)}$.オゾニドは常温 $\left(20^{\circ} \mathrm{C}\right)$ では約 2,000 時間の半減期を有する比較的安定な化合物で あるが，鉄イオンやアミン化合物が存在すると極めて不安 定となり，容易に分解する ${ }^{20)}$.

またオゾン劣化によるき裂の発生は，ゴム加硫物を伸長 することで促進される。このことはゴム加硫物の表面に形 成されたオゾンとゴムとの反応物からなる薄膜が伸長され ることにより破壊され，新たに露出したゴム表面にオゾン が反応して，き裂が成長すると考えられている ${ }^{17)}$.

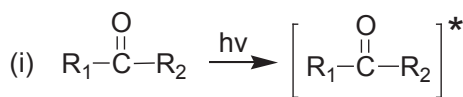

(ii)



図 $14 \mathrm{UV}(313 \mathrm{~nm})$ 照射によるIRの主鎖開裂反応促進作用機構（ケ 卜基の作用機構は文献説明内容を筆者が図式化） ${ }^{19)}$

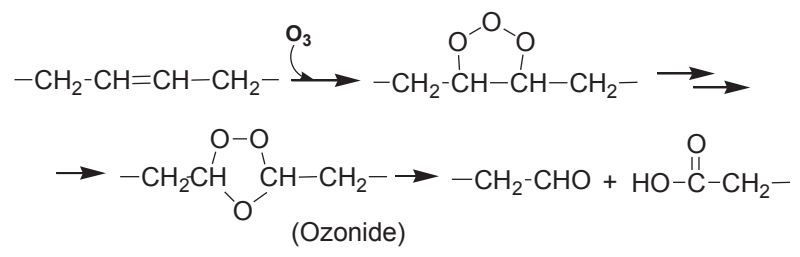

図15 ブタジエンユニットのオゾン劣化の作用機構 ${ }^{20)}$ 


\section{3. お わりに}

これまで二回にわたって各種ゴムの劣化機構について紹 介してきた，そこで主に取り扱ったのは，自動酸化反応を 主反応とする酸化劣化である．酸化劣化はゴムに限らず樹 脂でも発生し, その劣化機構もゴムと樹脂で変わることは なく，基本的には同じと考えられている。

しかし，ゴム製品は樹脂製品より酸化劣化を受けやすい ことも事実である。これは、ゴム分子がアモルファス構造 を有するため酸素の攻撃を受けやすく，またジエンゴムの アリルメチレン基のように，加熱によりポリマーラジカル を生成しやすい部位を有することが原因としてあげられ る. そのため一般的にゴム製品では, 樹脂製品の 10 倍近い 酸化防止剤が添加されている.

一方，ゴム製品は一般的に原料ゴムのほかに，充填剤， 可塑剂, 老化防止剂, 加硫用薬剤など多種類のゴム用副資 材の複合体で構成されており，そのため劣化による物性変 化を緩和しうる各種副資材を組合わせることで，劣化に伴 う物性変化を少なく抑えることも可能となる.

このため高い耐久性を有するゴム製品の配合処方の策定 には，各種ゴムの劣化機構をよく理解して，使用環境での 劣化状況を具体的に想定するとともに，老化防止剤に限ら ず全ての副資材の活用によるゴム製品の老化防止の可能性 を追求することが重要と考えられる.

今回, 各種ゴムの劣化機構の執筆に際し, 過去の劣化機
構に関する資料に加えて, 加硫物のモジュラスと硬さの変 化からの考察結果も一部紹介したが，これらは何れも状況 証拠であり，考察不充分な点もあると思われるが，ご叱正 頂ければ幸いである。

\section{References}

1）太智重光 日本ゴム協会誌 2018，91，435.

2 ）久保洋一郎 日本ゴム協会誌 1986，59，442.

3 ）曽根卓男 日本ゴム協会誌 $2015 ， 88,473$.

4 ） 山下晋三 日本ゴム協会誌 $1967,40,881$.

5 ) Pazur, R.; Troquet, M.; Gardette, J.-L. J. Polym. Sci., Polym. Chem. Ed., 1997, 35, 1689.

6 ）猿渡健市, 西野堯, 田畑豊 酸化防止剤ハンドブック; 大成社: 東 京, $1976 ; \mathrm{pp} 27$.

7 ）山崎聡 日本ゴム協会誌 2016, 89, 29

8 ) 秋山一; 第3 章 5 ポリウレタン. In 高分子の劣化機構と安定化技 術, 普及版 ; 大勝靖一, 編 ; シーエムシー出版 : 東京, 2005 ; pp266-279

9 ）伊藤邦雄 日本ゴム協会誌 $1985,58,832$.

10）村上伸茲 日本ゴム協会誌 $1990 ， 63 ， 384$.

11）Lynn, M. M.日本ゴム協会誌 1988，61，179；住友スリーエム 株式会社 訳

12）NOC技術ノートNo.500 日本ゴム協会誌 2002，75，371.

13）水野裕介日本ゴム協会誌 $1962 ， 35 ， 370$.

14）角岡正弘 日本ゴム協会誌 $1995 ， 68 ， 274$.

15）編集委員会 日本ゴム協会誌 2004， 77， 109.

16) Morand, M. J. Rubber Chem. Technol., 1966, 39, 537.

17）久留宮弘幸 日本ゴム協会誌 $1972 ， 45 ， 184$.

18）村上健吉；高杉純生 日本ゴム協会誌 1977，50，65.

19) Ng, H. C.; Guillet, J. E. Photochem. Photobiol., 1978, 28, 571.

20）太智重光 日本ゴム協会誌 2014，87，284. 